\title{
UNDANG-UNDANG SULTAN ADAM 1835 DALAM PERSPEKTIF SEJARAH HUKUM
}

\begin{abstract}
Abdurrahman *
ABSTRACT

Undang-undang Sultan Adam sebagai perangkat bukum peninggalan masa lalu kurang mendapatkan perhatian baik dari kalangan para abli bukum maupun dari sejarawan, bahkan sampai sekarang ini teks peraturan itu belum pernah ditulis dalam bahasa Indonesia karena sampai saat ini dokumen itu masih tertulis dalam bahasa Melayu/Banjar disertai terjemahannya dalam bahasa Belanda. Karena itu wajar apabila dokumen bukum itu tidak tersebar secara meluas dikalangan para ilmuan. Di sampimg itu dokumen bukum itu juga penting sebagai informasi bagi generasi mendatang tentang keberhasilan yang pernah dicapai oleh nenek moyang mereka dimasa lampau dalam menetapkan bukum di dalam masyarakatnya.
\end{abstract}

Kata Kunci : Undang-undang, Sultan Adam, dan Ulama.

Uraian singkat ini adalah merupakan sebuah bahasan mengenai naskah hukum peninggalan zaman kerajaan Banjar di Kalimantan Selatan yang dibuat dan ditetapkan oleh Sultan Adam Al-watsikubillah, Sultan Banjar yang memerintah pada tahun 1825-1857. Naskah hukum yang dikenal dengan nama "Undang-Undang Sultan Adam". Ditetapkan pada tahun 1835 jadi sudah berusia 165 tahun.

Sebagai sebuah dokumen historis, sejak dulu hingga sekarang ia mengandung prinsip-prinsip hukum yang hidup (the living law) dari Masyarakat Banjar yang dipertahankan oleh kerajaan Banjar yang tentunya berlaku sampai dengan dibubarkannya kerajaan Banjar oleh pemerintah Belanda pada tahun 1860. Mungkin naskah ini adalah satu-satunya dokumen historis peninggalan Pemerintahan kerajaan Banjar sejak berdiri pada tahun 1526 hingga dibubarkannya kerajaan pada tahun 1860.

*Hakim Agung pada Mahkamah Agung RI dan dosen pada beberapa program Pascasarjana (S2/S3) di Indonesia. 
Bagaimana ketentuan hukum ini dilihat dari segi sejarah hukum? Istilah sejarah hukum (legal historis) mengandung tiga makna:

1. Sejarah hukum sebagai suatu disiplin kajian ilmu hukum.

2. Sejarah hukum sebagai sebuah aliran dalam kajian hukum.

3. Sejarah hukum sebagai satu bentuk penafsiran ketentuan hukum.

Dalam bahasan ini diupayakan adanya keterpaduan antara ketiga aspek tersebut dengan menjadikan undang-undang Sultan Adam sebagai objek kajiannya.

Pertama sejarah hukum sebagai suatu disiplin kajian ilmu hukum adalah dalam kaitan adanya kerangka kajian ilmu hukum. Soerjono Seokanto dalam satu tulisannya menggambarkan kerangka disiplin ilmu hukum itu sebagai berikut:

1. Ilmu-Ilmu Hukum

a) Ilmu tentang kaidah yang menelaah hukum sebagai kaidah atau sistem kaidah-kaidah dengan dogmatik dan sistematik hukum.

b) Ilmu pengertian, yakni ilmu tentang pengertian-pengertian dasar dari sistem hukum sebagai berikut:

(1) Subjek hukum.

(2) Hak dan kewajiban.

(3) Peristiwa hukum.

(4) Hubungan hukum.

(5) Objek hukum.

c) Ilmu tentang kenyataan yang menyoroti hukum sebagai perangkat sikap tindak atau peri kelakuan yang terdiri dari:

(1) Sosiologi hukum, yaitu suatu cabang ilmu pengetahuan yang secara analitis dan emperis mempelajari hubungan timbal balik antara hukum dan gejala-gejala sosial lainnya.

(2) Antropologi hukum, yang terutama mempelajari pola-pola sengketa dan penyelesaiannya pada masyarakat yang mengalami proses modernisasi.

(3) Psikologi hukum, yakni suatu cabang ilmu pengetahuan yang mempelajari hukum sebagai suatu perwujudan daripada jiwa manusia.

(4) Perbandingan hukum yang memperbandingkan sistem-sistem hukum yang berlaku di dalam satu atau beberapa masyarakat.

(5) Sejarah hukum yang mempelajari perkembangan dan asal usul dari pada sistem hukum dalam suatu masyarakat tertentu. 
2. Politik Hukum yang mencakup kegiatan memilih nilai-nilai dan menterapkan nilai-nilai tersebut.

3. Filsafat Hukum yang mencakup kegiatan:

a) Perenungan nilai-nilai.

b) Perumusan nilai-nilai.

bersitegang. ${ }^{1}$

c) Penyerasian nilai-nilai yang berpasangan tetapi kadangkala

Dalam kerangka tersebut di atas, sejarah hukum dilihat sebagai satu cabang ilmu hukum yang termasuk ilmu tentang kenyataan, di mana sejarah hukum diartikan sebagai ilmu yang mempelajari tentang perkembangan dan asal usul daripada sistem hukum dalam suatu masyarakat tertentu. Karena itu mempelajari tentang Undang-Undang Sultan Adam yang merupakan bagian dari perkembangan hukum yang berlaku dalam masyarakat Banjar adalah satu kajian sejarah hukum. Kerangka yang ditawarkan oleh Soerjono Soekanto tersebut di atas adalah lebih sistematika dan lengkap bila dibandingkan dengan kerangka yang ditawarkan oleh pakar hukum Belanda Van Apeldoorn.

Dalam tulisannya Van Apeldoorn membicarakan kerangka kajian hukum dalam tiga bidang yaitu:

\section{De Rechtskunst (Semi Hukum).}

Menurut pendapatnya didahulukan seni hukum, adalah karena seni hukum sebagai kesenian hidup bersifat primer, karena tidak ada pergaulan hidup manusia yang tidak ada hukumnya, karenanya tidak mungkin tanpa seni hukum walaupun bagaimana primitifnya masyarakat yang bersangkutan. Seni hukum sudah dipelajari lama sebelum ada ilmu hukum. Ia muncul dalam berbagai pepatah hukum atau simbol-simbol hukum. ${ }^{2}$

Tercakup dalam bidang ini adalah:

a) De wetgeving (Perundang-undangan).

Tot de rechtskunst behoort tegenwordingin de eerste plaats de kunst der wetgeving. Men pleegt deze te onderscheiden in: sistematis dari kaidah-kaidah hukum yang berlaku pada waktu yang tertentu dalam masyarakat tertentu. Sebagaimana telah kita lihat, kaidah-kaidah adalah pertimbangan nilai, pandangan manusia tentang apa yang seharusnya dilakukan dan apa yang seharusnya tidak

1Soerjano Soekanto, Pengantar Sejarah Hukum, (Bandung: Alumni, 1979), h. 13-14.

${ }^{2}$ L.J, Van Apeldoorn, Inleding tot de Studies van het Nederlands, (Leiden: Recht, 1952), h. 294 . 
dilakukan dan karenanya hal demikian tidak dapat menjadi objek dari ilmu hukum.

2. Rechtswetenscap (Ilmu Hukum).

Het recht als maatschappelijk Verschijnsel, dus als geheel Van in de samenleving heersende rechtswetenschap. Deze Stelt zich evenmim als enige andere wetenschap levreden met het beschrijven $V$ an de waargenomen Verschijnselen, maar tracbdie ook wit bun causalen Samenhang met andere Verschijnselen, zoovol mogelijk, te Verklaren, Terbreiking van dit doel bedient zij zichvan drieerlei methode:

- De sociologisch, die dan samanhang van het recht met andere maatschappelijke verschijnsel onderzoekt;

- De historische, die den historischen samenhang m.a.w de bistorische onwikkeling van het recht navorst.

- De rechts vergelijkende, die de rechts ordmengen Van Verschillende, die rechtsordeningen $V$ an Verschillende rechtsgemenschappen met elkar vergelijkt. ${ }^{3}$

Hukum sebagai gejala masyarakat, jadi sebagai keseluruhan kebiasaankebiasaan hukum yang berlaku di dalam masyarakat adalah objek dari ilmu hukum, sebagai juga dengan tiap-tiap ilmu lainnya ia tak puas dengan mencatat gejala-gejala yang dilihatnya, akan tetapi sebanyak mungkin juga menerangkan tentang sebab akibat dengan gejala lainnya untuk mencapai tujuan tersebut ia memakai tiga buah cara:

- Sosiologis, yang menyelidiki pertalian hukum dengan gejala-gejala masyarakat lainnya.

- Sejarah, yang menyelidiki pertalian hukum dari sudut perjalanan sejarahnya atau dengan perkataan lain yang menyelidiki pertumbuhan hukum secara historis.

- Perbandingan hukum, yang membandingkan tatanan-tatanan hukum dari pelbagai masyarakat hukum.

Berdasarkan pada tiga cara pendekatan tersebut Van Apeldoorn menetapkan ada tiga bidang keilmuan yang digunakan sebagai kerangka kajian hukum yang termasuk dalam bidang ini, yaitu: sosiologi hukum, sejarah hukum dan perbandingan hukum. Namun berbeda dengan ilmu hukum dogmatik dan ajaran hukum umum Van Apeldoorn, sejarah hukum, juga sosiologi hukum dan perbandingan hukum dalam merupakan ilmu hukum yang hakiki yaitu sebagai ilmu hukum dalam artian yang sebenarnya.

Selain itu dalam bukunya Van Apeldoorn mengemukakan beberapa hal yang menarik berkenaan dnegan sejarah hukum ini, bahwa:

${ }^{3}$ Ibid., h. 320. 
"Historisch onderzoek beef dus een bevrijdend karakter: het bevrijds ons Vooroordelen, het maakt dat wij het bestaande mei zonder meer als vanzelf sprekend aanvaarden maarcritisch tegenover gaan staan. Hoe nunder met het Verleden kant, hoe gro ter gevoor man loops en door to worden overboorst" ${ }^{4}$

Penyelidikan secara sejarah mempunyai sifat membebaskan kita dari prasangka-prasangka, ia menyebabkan bahwa kita tidak begitu saja menerima yang ada sebagai hal yang sedemikian, akan tetapi menghadapinya secara kritis. Makin sedikit kita mengenal masalalu akan makin besar bahaya yang menguasai kita.

Dikemukakannya pula: "Historisch onderzuek dot ons de socials factoren kennen, aardoor bapaide instellingan in het leven zijn groepen. Enzo kan het ons loren, of die instellingen ook nog passew onzsn tijd, door wa; of zij door Verordering van maatsubapelijke to stande, waaraan zij haar ontstaan denken, haar ouden bestaan groud hebben verloren. Allen wie al het bestaande critiekloos wemst to aanvaarden, onhoud zich zorgvuldig han historisch onderzoek er volvalgedrrs den raad van den Romcinsen jurist Meratius, "Et ideorationar eorarumquae constituuntur inquivinom oporten-oporten alioquin multa ex his eune cant sunt subvertuuntur" ${ }^{5}$

(Penyelidikan secara sejarah, membuat kita mengenal faktor-faktor sosial, karena yang dilahirkan lembaga-lembaga tertentu. Dengan demikian ia dapat mengajarkan kepada kita, apakah lembaga-lembaga itu masih cocok pada masa kini, atau telah kehilangan dasar wujudnya disebabkan karena perubahan keadaan masyarakat. Hanya mereka yang hendak menerima segala yang ada dengan tanpa kritik, janganlah hendaknya menga.dakan penyelidikan secara sejarah dan ikutilah nasihat ahli hukum Romawi Narantius yang mengatakan: "Karena itu janganlah orang menyelidiki sebab-sebab suatu lembaga hukum diadakan karena kalau demikian banyak hal yang sudah pasti akan tergulingkan).

Pendapat lain yang patut dicatat di sini adalah pendapat dari pakar hukum Belanda J.H.P Bellefroid yang membicarakannya dalam kaitan dengan "Verdeling der rechtswetenschap" atau pembagian ilmu hukum. Dikatakannya "De rechtslvetenschap is te verdelen in vijft of zonderlijk wetenschappen, die onderscheideriiijk tot voorwerp hebben, de rechtsriogmatik, de rechtsgeschiedenis, die rechts Vergelijking, de

${ }^{4}$ Ibid., h. 327.

5Ibid., h. 327. 
rechtspolitiek, en de algemene rechtsleer. ${ }^{6}$ (Ilmu Hukum dapat dibagi dalam lima ilmu khusus dengan masing-masing objeknya, yaitu ilmu hukum dogmatik/dogmatik hukum, sejarah hukum, perbandingan hukum, politik hukum dan ajaran hukum umum).

Khusus mengenai sejarah hukum Bellefroid menyatakan: "De rechtsgescheidenis als wetenschap beschowd, houdt zich berig met de vroegere rechtssteelsels, die tot de vorming van het beztaande hebben medegewerkt, zij voor het goed begrip van het thans geldende recht om misbaar. Wan in de rechtsgeschiedenis volgen wij den ontwikekelingsgaaq die het hedendaagee recht aan vroegere rechtsstelsels heefs ontleend". (Sejarah hukum dipandang sebagai ilmu pengetahuan yang mempelajari tatanan-tatanan hukum dahulu yang membantu terbentuknya hukum yang ada. Ia sangat diperlukan untuk dapat mengartikan dengan baik hukum yang berlaku sekarang, karena dalam sejarah hukum kita mengikut jalan perkembangan dari lembaga hukum yang diambil oleh hukum yang ada sekarang ini dari tatanan hukum masa lalu).

Sebagai tambahan mengenai pengertian sejarah hukum dapat dikutib pendapat dua orang pakar hukum kita yaitu Kusnadi Poedjosewajo dan E. Utrecht. Dalam uraiannya "Ilmu Pengetahuan Sejarah Hukum" ia menyatakan bahwa Tata Hukum adalah suatu gejala sejarah. Tata hukum yang berlaku sekarang berlainan daripada tata hukum pada masa-masa yang silam, juga dapat berbeda daripada tata hukum dalam masa yang sekarang sudah tentu terkandung anasir dari tata hukum dahulu sekedar diakui berlakunya, sebaliknya di dalam tata hukum sekarang terletak tunas, tunas tentang tata hukum yang akan terwujud di kemudian hari, gejala ini dapat pula merupakan objek dari ilmu pengetahuan hukum tersendiri yakni sejarah hukum. ${ }^{8}$

Sedangkan E. Utrecht dalam bukunya mengemukakan bahwa yang menjadi tugas sejarah hukum ialah menyelidiki perkembangan hukum yang kontinu, kita hanya mengerti benar-benar suatu hukum pada waktu sekarang, apabila kita mengetahui pula perkembangannya di sejarah. Kita hanya mengerti benar-benar suatu hukum pada waktu sekarang apabila kita telah mengetahui pula anasir-anasirnya yang berasal dari suatu hukum yang sekarang tidak berlaku lagi.'

J.H.P. Bellefroid, Inleiding tot de Rechtswetenschap in Nederlands, (Nijmingen Utrecht, Dakker \& van de Verg NV., 1952).

${ }^{7}$ Ibid., h. 17-18.

${ }^{8}$ Kusnadi Poedjosewajo, Pedoman Pelajaran Tata Hukum Indonesia, (t.tp: Universitas, 1962) h. $10-11$.

${ }^{9}$ E. Utrecht, Pengantar dalam Hukum Indonesia, (Jakarta: Ichtiar, 1966) h. 71. 
Selanjutnya patut pula dikutib pendapat dari Mochtar Kusumaatmadja pada waktu ia menjabat sebagai menteri kehakiman pada sambutan pembukaan "Simposium Sejarah Hukum" yang diselenggarakan oleh Badan Pembinaan Hukum Nasional (BPHN) di Jakarta tanggal 1 April 1975 di mana ia mengatakan: "Perbincangan mengenai sejarah hukum mempunyai arti penting dalam rangka Pembinaan Hukum Nasional, oleh karena usaha pembinaan hukum tidak saja memerlukan bahan-bahan hukum masa kini saja, akan tetapi juga bahan-bahan hukum dari masa lampau. Melalui sejarah hukum kita akan mampu menjaga aspek hukum Indonesia pada masa yang lalu, hal mana akan dapat memberikan bantuan kepada kita memahami kaidah-kaidah serta institusi-institusi hukum yang ada dewasa ini dalam masyarakat bangsa kita".

Pada bagian lain ia menyatakan mengani arti penting dari sejarah hukum bagi Pembinaan Hukum Nasional kita bahwa ungkapan-ungkapan melalui sejarah hukum akan memperlihatkan kepada kita tentang kemungkinan adanya lembaga serta kaidah dalam hukum kita yang masih dapat diperkembangkan sehingga serasi dengan apa yang dikenal dengan hukum modern dewasa ini. Disinilah letak antara lain arti penting dari sejarah hukum bagi usaha Pembinaan Hukum Nasional. ${ }^{10}$

Akhirnya menarik juga untuk dikemukakan apa yang menjadi kesimpulan dari Soerjono Soekanto dalam bukunya tentang "Sejarah Hukum" di mana ia menyatakan antara lain bahwa sejarah hukum dapat memberikan pandangan yang luas bagi kalangan hukum. Hukum tak akan mungkin berdiri sendiri, karena senantiasa dipengaruhi oleh aspek-aspek kehidupan lain, dan juga mempengaruhinya. Hukum merupakan suatu hasil perkembangan dari salah satu aspek kehidupan manusia. Hukum masa kini merupakan hasil perkembangan dari hukum masa lampau, dan hukum masa merupakan dasar bagi hukum masa mendatang. Sejarah hukum akan dapat melengkapi pengetahuan kalangan hukum mengenai hal-hal tersebut. ${ }^{11}$

Dalam akhir kesimpulan dikemukakan bahwa sejarah hukum akan dapat mengungkapkan tentang fungsi dan efektivitas lembaga-lembaga hukum tertentu. Artinya, pada situasi-situasi semacam apakah suatu lembaga hukum benar-benar dapat berfungsi atau malahan tidak berfungsi sama sekali ini sangat penting terutama bagi pembentuk dan penegak hukum akhirnya, sejarah 1976), h. 6.

${ }^{10}$ Badan Pembinaan Hukum Nasional, Simposium Sejarah Hukum, (Bandung: Binacipta,

${ }^{11}$ Soerjano Soekanto, Pengantar Sejarah ..., h. 40. 
hukum memberikan kemampuan untuk dapat menilai keadaan-keadaan yang sedang dihadapi, dan memecahkan masalah-masalahnya. ${ }^{12}$

Mengacu pada berbagai pandangan dan pendapat sebagaimana dikemukakan di atas, akan menjadi sangat relevan bilamana kita membicarakan kembali Undang-Undang Sultan Adam (1835) dalam rangka memahami perkembangan hukum di Tanah Banjar, mengingat ketentuan tersebut dapat dipandang sebagai hasil interaksi dari hukum adat dan hukum Islam yang terhubungkan secara jalin menjalin antara satu dengan yang lain dan akan memberikan kejelasan terhadap pranata-pranata hukum yang masih tetap hidup walaupun telah mengalami perubahan di Tanah Banjar dewasa ini.

Pembahasan tentang sejarah hukum tidak hanya terbatas pada sejarah hukum sebagai salah satu cabang dari ilmu hukum tetapi ia juga terkaut dan akan dapat dipahami melalui satu aliran dalam ilmu hukum yang disebut "Historical Jurisprudence" atau aliran sejarah hukum dan melalui "Penafsiran Sejarah Hukum" walaupun untuk dua hal ini hanya akan dibahas secara sepintas. berikut:

Mengenai aliran sejarah hukum, Brian H. Bix mengungkapkan sebagai

"An approach to understanding Law in Which history plays an important role. That legal Systems may reflact the distinctive social character (and even climaks) of their country is an idea that goes back at least to Montesquieu (1689-1755). The view that hisyory has significant role in explaining the current state of law, as well as it is past development and likely future direction, is connected primarily which two figures: Friedrich Carl von Savigny (1719-1861) and Sir Henry Maine (18221888). ${ }^{13}$

Bagaimana pandangan kedua tokoh ini dikemukakannya sebagai berikut:

"Writer associated with historical Jurisprudence have V aried significantly in their beliefs and asssertions, but many emphasized the importance of the Customs and traditions of particular Cultural as W ay of explaining the way law did, and peerhaps also the way it should, decelop. Historical Jurisprudence was seen to be in sharp contrast to natural law theory and other theories that emphasize a single right model for law everywhere. At the same time, the historical Jurisprudence of both savigny and Maine can be seen as responses to a Cenain kind od legal pasitivism. Which saw law as no more and ho less iharr whatever the sovereign commad, Writers such as Savigny

${ }^{12}$ Soerjano Soekanto, Pengantar Sejarah ..., h. 41.

${ }^{13}$ Brian H. Bix, A Dictionory of Legal Theory, (Oxford: Oxford University Press, 2004), h. 88 . 
opposed atternpts to Impose a rationalization or codification of nation laws (Savigny appeared not so much to oppose codification as such but only codification at the wrong time. Codification might be appropriats at the height of a cultures maturity, but at time of development or decline it would be counterproductive". ${ }^{14}$

Sebagai bandingan Roscou Pund dalam satu tulisannya menyebutkan ada tiga persoalan pokok dari aliran sejarah hukum ini, yaitu:

"As its First tenet it held that law was found, not mode, that is, is was a theory of the traditional element in modern law because the confident disregated of that element and belief that law might be mode out of whole cloth by a sheer effort of Juristic reason had led to the unworkable probibitions upon judicial interpretation of the Prusion code, to the crude legislation as to extinstion off personality which Savigny exposed at such lenghth in his "system of the legislation upon divorce which be disects bistirocally in his tract upon legislation and jurisprudence.

Secondly, The historical school througnont its existence beld to same form if idelaistic interpretation of legal history. Savigny was unconsciously much under the influende of the ideas of the law of nature school in which he had been trained He assemed the seventeenth and eighteenth century dactrime that law was only declaratory, and simply put a bistorical foundation under it in place of its original pgilosiphical foundation. Nothing could have been better adapted to the demands of tiris new foundation for an old way of thinking than the Hegelian philosophy of Histroy.

Third, the historical school insisted on the social pressure behind rules where the philosophical school of the preceding centuries but insisted in the intrinsie force of the just rules as binding upon the moral entity and the analytical school later wasted upon the force of politically organized society. ${ }^{15}$

Kerangka pikir sebagaimana yang dikemukakan oleh Friedrich Kari Von Savigny yang dianggap sebagai tokoh utama aliran sejarah hukum sebagaimana dikemukakan di atas dapat dijadikan "Kerangka Theory" bilamana kita melakukan analisa secara mendasar terhadap Undang-Undang Sultan Adam yang pernah berlaku di lingkungan kerajaan Banjar sejak tahun 1835 yang masih perlu dipersoalkan apakah masih tetap berlaku ketika Belanda memproklamasikan bubarnya kerajaan Banjar pada tahun 1860.

Persoalan ketiga yang terkait dengan pengertian sejarah hukum adalah berkenaan dengan penafsiran sejarah hukum "Tentang Pengertian Penafsiran

${ }^{14}$ Ibid., h. 88-89.

${ }^{15}$ Roscoe Pound, Interpretation of Legal History, (Florida: Wm W Gaunt \& Soon Inc, 1985) h. 17-18. 
Sejarah Hukum dapat dikutib kembali pendapat J.H.P Bellefroid yang antara lain menyatakan berkenaan dengan "Uitlegging an aanvulling der wet" (menafsirkan dan melengkapi undang-undang). Mengenai "Historisch uitlegging" (Penafsiran sejarah) ia mengemukakan:

"Brengt de grammaticale witlegging ons nader tot de kennnis van den objectieven zin der wet, zonder nochtans daarbij de bedoling van den wetgever te verwaarlozen, de nistoris uitlegging is daarentegen in zonderheids op die bedoeling gericht. De wet word bistorisch witgelegd, Wanner haar zin met behulp der wetsgeschiede nis of der rechtsgeschiedenis wordt be paald". ${ }^{16}$

Kalau penafsiran gramatikal membawa kita lebih dekat pada arti yang objektif dari undang-undang, maka dengan tidak mengabaikan maksud dari pembentuk undang-undang, penafsiran historis dengan sengaja ditujukan kepada maksud itu. Undang-Undang ditafsirkan secara historis, apabila artinya ditetapkan dengan bantuan sejarah undangundang atau sejarah hukum.

Dalam kaitannya dengan Undang-Undang Sultan Adam, penafsiran sejarah walaupun sebenamya berkaitan dengan undang-undang secara formal, tetapi juga dapat digunakan untuk mengartikan teks-teks dari Undang-Undang Sultan Adam dengan memahami dalam suasana apa undang-undang itu dibuat. Sebenarnya, di samping penafsiran sejarah hukum, pemahaman UndangUndang Sultan Adam diperlukan dengan penafsiran Gramatikal atau penafsiran secara kebahasan, mengingat naskah tersebut disusun dalam bahasa Banjar Kuno yang terkadang maknanya sulit dipahami.

Dalam kajian hukum Undang-Undang Sultan Adam ini ditempatkan dalam kerangka kajian Hukum Adat. Pakar hukum adat Van Vollenhoven (1874-1933) dalam bukunya "Het Adatrecht Van Nederlandsch Indie" (1905) mengungkapkan secara sepintas pada waktu membicarakan tentang $V$ indplaatsen van het adatrecht (sumber-sumber tempat menemukan hukum adat) salah satu diantaranya adalah "Verordeningen van vorsten en boefden" (Peraturan para raja dan kepala-kepala kemasyarakatan) yang kemudian disebut "geshreven adatrecht" atau "hukum adat tersurat", sebagai lawan dari "ongeschreven adatrecht" atau "hukum adat yang tidak tertulis". Mengenai hal itu ia menyebutkan "Vorstenedikten in dezen trant zijn nog uit tal van streken over, en komen in de tweede afdeeling bij Atjeh (sarakata's) bij zuid Borneo (Sultan Adam) bij Bolaang Mongondou en ${ }^{17}$

${ }^{16}$ J.H.P. Bellefroid, Inleiding tot de Rechtswetenschap ..., h. 110-111.

${ }^{17}$ Van Vollenhoven, Het Adatrecht V an Nederlandsch Indie, (t.tt: t.tp, 1905), h. 113. 
Dua belas tahun kemudian, Van Vollenhoven dalam publikasi ilmiah yang dikelolanya selaku komisi untuk Hukum Adat Koninklijk Institut voor de Taal, Land an volkenkunde van de Nederlandsch Indie "Adatrechts Bundel" Jilid XIII (1917) mempublikasi kembali tulisan mantan Gubernur Kalimantan A.M. Joekes sebagai Gubernur Kalimantan pada masa Pemerintahan Hindia Belanda (1891-1894) tentang undang-Undang Sultan Adam yang pernah dimuat dalam Majalah De Gids pada tahun 1881 yang berarti tulisan tersebut dibuat sepuluh tahun sebelum ia menjabat sebagai Gubernur. Naskah tersebut ditulis dengan huruf latin bahasa Melayu Banjar disertai terjemahan dalam bahasa Belanda dengan disertai penjelasan (toelichtingen) terutama berkenaan dengan aspek kebahasaan.

Dalam publikasi Adatrechts Bundel (1917) naskah Joekes diperbaiki kembali terutama berkenaan dengan peristilahan-peristilahan. Selain memuat "Teks en Vertaling van het edict, publikasi dalam Adatrechts Bundel memuat juga "Taalkundige aantekeningen van Joekes" yaitu catatan-catatan yang dibuat oleh Joekes mengenai aspek kebahasaan juga memuat "Toekchting van Joekes" yaitu beberapa penjelasan yang dibuat oleh Joekes tentang beberapa pengertian yang terkandung dalam beberapa pasal.

Semenjak diterbitkannya dalam Adatrechts Bundels 1917 UndangUndang Sultan Adam menjadi cukup populer di kalangan para pengkaji Hukum Adat, khusus Hukum Adat Banjar baik di kalangan pakar Belanda maupun pakar pribumi yang tertarik untuk mendalami sebuah aturan hukum yang dibuat oleh seorang Raja dari kerajaan Banjar, Sultan Adam Al-Watsiq Billah yang memerintah pada tahun 1825-1857 dan menetapkan peraturan tersebut pada tahun 1835 .

Siapa sebenamya Sultan Adam Al-Watsiq Billah atau yang lebih populer dengan sebutan Sultan Adam itu? Nama ini sebenarnya sudah cukup terkenal walaupun hanya secara sepintas, karena cukup banyak diungkapkan dalam buku-buku sejarah Nasional dalam rangka menguraikan latar belakang terjadinya perang Banjarmasin atau perang Banjar (1859-1904). Karena berawal dari wasiat Sultan ini ditetapkan bahwa yang akan menjadi pewaris tahta kerajaan Banjar adalah cucu beliau Pangeran Hidayatullah, namun Belanda turut campur dan memaksakan kehendaknya mengangkat Pangeran Tamjidillah yang juga cucu Sultan Adam namun tidak disenangi oleh rakyat.

Sultan Adam Al-Watsiq Billah memerintah kerajaan Banjar dalam tahun 1835-1857. Dalam "Encyclopaedia van Nederlandsch Indie"18 dikemukakan:

${ }^{18}$ Encyclopaedia van Nederlandsch Indie, (t.tt: t.tp, 1917), h. 19. 
"ADAM (ALWAS SIKH BILLAH) - was de voorlaatste Sultan van Banjarmasin, na wins dood, ten gevolde van oneenighedenover de troorrsopvalging, een geduchte - opstan nit brak, die eindigde net de iniijving van hetrijk".

Kutiban ini menunjukkan bahwa Sultan Adam Al-Watsiq Billah adalah Sultan Banjarmasin satu sebelum terakhir, yang mana setelah kematiannya mengakibatkan timbulnya perselisihan faham mengenai penggantian tahta dan pecahnya pemberontakan yang gawat serta berakhir dengan jatuhnya kerajaan Banjar. Pendapat ini walaupun tidak semuanya benar, namun patut dihargai karena sebagai sebuah ensiklopedi yang dibuat oleh orang Belanda telah memasukkan Sultan Adam sebagai tokoh, sedangkan pada masa sekarang ensiklopedi yang diterbitkan pada setelah kemerdekaan tidak memasukkan Sultan Adam sebagai tokoh bangsa pada lalu, Pandangan yang ditulis dalam Encyclopaedia van Nederlandsch Indie ini dapat dijadikan sebagai bandingan bagaimana pemahaman penulis Belanda tentang tokoh kita ini.

Bagi masyarakat dan warga Kalimantan Selatan khususnya, nama Sultan Adam bukanlah suatu hal yang asing, makamnya di Martapura cukup banyak diziarahi orang. Namanya diabadikan sebagai nama jalan baik di kota Martapura maupun di kota Banjarmasin. Namanya juga diabadikan untuk sebuah Perguruan Tinggi Hukum di Banjarmasin, Sekolah Tinggi Ilmu Hukum Sultan Adam (STIHSA) dan juga dijadikan nama Taman Hutan Raya Sultan Adam Riam Kanan, sebagaimana dikukuhkan dengan Keputusan Presiden No. 51 Tahun 1989 dan diresmikan oleh Presiden pada tanggal 18 Desember 1989, dan acara Haulan (peringatan wafatnya) selalu digelar setiap tahun sebagai even daerah.

Sultan Adam Al-Watsiq Billah adalah seorang Sultan dari Kerajaan Banjar, akan tetapi sebagai Sultan yang beberapa terdapat perbedaan pendapat dikalangan para penulis. Dalam Manaqib Sultan Adam Al-Watsiq Billah yang dibacakan pada Haul ke-148 (4 Juni 2001) ${ }^{19}$ yang kemudian diungkapkan kembali oleh Abu Daudi dalam bukunya dinyatakan:

"Kalau kita memperhatikan ranji atau silsilah Kerajaan Banjar sejak raja pertama sampai kepada raja yang ke tujuh yang Pemerintah Banua Banjar ini, masih menganut kepercayaan animism (kepercayaan ... ruh) yang dimulai dari Pangeran Suryanata (Surya Cipta/Pangeran Surya Diwangsa, Carang Lakan, Pangeran Sekar Sungsang (Sari Kaburangan), Maharaja Sukarama, pangeran Mangkubumi dan Pangeran Tumenggung

${ }^{19}$ Team Penyusun, Manaqid Sultan Adam Al-Watsiq Billah Martapura Kalimantan Selatan, (Kalimantan Selatan: Yayasan Sultan Adam Al-Watsiq Billah, 2001), h. 6. 
(yang terkenal dengan sejarah Perang Bungur) di sepanjang sungai Barito, Daha (Nagara), Kahuripan (Amuntai) Hulu Sungai Utara, maka Sultan Adam ini termasuk raja yang ke-18. Tetapi kalau ditinjau dari sejak kerajaan Banjar ini dipegang oleh Pangeran Samudera (raja pertama yang menganut agama Islam, dengan gelar Sultan Suriansyah), maka Sultan Adam ini adalah yang ke-12 dari silsilah Kesultanan Banjar". ${ }^{20}$

Pandangan ini adalah didasarkan pada ranji atau silsilah yang diikuti oleh keturunannya yang lebih dikenal dengan sebutan versi pedatuan. ${ }^{21}$ Pendapat ini juga dikemukakan oleh seorang ulama terkemuka kita Syekh Abdurrahman Shidiq Al-Banjari atau lebih dikenal dengan Syekh Abdurrahman Shidiq Sapat (1857-1939) dalam tulisannya yang terkenal "Risalah Sejaratul Arsyadiyab" yang juga menyebut Sultan Adam Al-Watsiq Billah sebagai Sultan yang ke-18. ${ }^{22}$

Berbeda dengan apa yang dikemukakan di atas Eisenberger menempatkan Sultan Adam sebagai Sultan ke-20 dalam urutan raja-raja Banjar yang dimulai dari Soeria Anata. ${ }^{23}$ Pendapat ini diikuti oleh Amir Hasan Bondan $^{24}$ dan Yusuf Halidi serta ${ }^{25}$ Noorlander. ${ }^{26}$ Pendapat ini diikuti oleh M. Idwar Saleh. ${ }^{27}$ Pendapat lain adalah dari Kyai Haji Januri bin Haji Roys, Sultan Adam al-Watsiq Billah adalah merupakan Sultan ke-11 dalam urutan raja-raja Banjar. ${ }^{28}$ Sedangkan Gazali Usman dalam bukunya menempatkan sultan Adam

${ }^{20}$ Abu Daudi, (t.tt: t.tp, 2003), h. 24.

${ }^{21}$ H. Gusti Shuria Rum, Ranji/Silsilah Raja/Sultan Kerajaan Banjar Versi Pedatuan, Makalah pada Acara Sarasehan Sejarah Kerajaan Banjarmasin, Banjarmasin, 2003, h. 6.

${ }^{22}$ Syekh Abdurrahman Shiddiq, Risalah Sejaratul Arsyadiyah, (Singapura, Jakarta: Maktabaah Ahmadiyah, 1937), h. 100.

${ }^{23}$ J. Eisenberger, Nota Betreffende Godsdienstige Rechtspraak en de Posietie der Godsdienstige Functionarissen in The Afdeeling Banjarmasin en Hoeloe Soengai der Residentis en Oosterafdeeling Banjarmasin en Hoeloe Soengai der Residentie Zuider en Oosterafdeeling Borneo, (Kern Colectie, 1936), h. 113.

${ }^{24}$ Amir Hasan Kiai Bondan, Suluh Sejarah Kalimantan, (Banjarmasin: Fajar,1953), h. 68.

${ }^{25}$ Yusuf Halidi, Ulama Besar Kalimantan Selatan Syekh Muhammad Arsyad Al Banjari, (Surabaya: Al Ihsan, 1984), h. 10.

${ }^{26}$ Johanes Cornelis Noorlander, Banjarmasin en de Compagnie in de tweede helf der 18de Eeun, (Leiden: M. Dubbeldeman, 1935), h. 90.

${ }^{27}$ M. Idwar Saleh, Banjarmasin, Selayang Pandang Mengenai Bangkitnya Kerajaan Banjarmasin, Posisi, Fungsi, dan Artinya dalam Sejarah Indonesia dalam Abad ke 17, (Bandung: Balai Pendidikan Guru, 1957), h. 102.

${ }^{28}$ Kyai Haji Januri bin Haji Roys, Sejarah Kerajaan Banjar, (Singapura: Al Ahmadiyah, 1975), h. 19. 
pada urutan yang ke-16 dalam silsilah para raja-raja Banjar. ${ }^{29}$ Pendapat ini diikuti dalam buku "Sejarah Banjar" yang diterbitkan oleh Pemerintah Provinsi Kalimantan Selatan. ${ }^{30}$ Adanya keragaman pendapat ini menuntut kita untuk melakukan kajian sejarah yang lebih mendalam.

Di kalangan para penulis kita temukan beberapa penilaian tentang pribadi Sultan Adam baik dari kalangan orang Belanda maupun dari kalangan orang Indonesia atau tepatnya orang daerah. Helius Sjamsudin dalam disertasinya mengemukakan bahwa sebagai kepala keluarga Sultan Adam pada tahun 1855 telah berusia 84 tahun. Baik Residen PH.AB. Van Hengst (1851-1853) maupun Residen A Van de ven (1853-1855) dari Banjarmasin melaporkan bahwa Sultan Adam adalah seorang yang baik hati, tetapi lemah. Ia patuh sekali pada istrinya, Nyai Ratu Kemala Sari, yang semula adalah selir ayahnya. Kelemahan dari Sultan Oktogenonan itu ditunjukkan dalam ketidakmampuannya menengahi apalagi menghentikan perselisihan antara anak-anaknya dan cucunya yang menyebabkan jatuhnya korban. Pada tahun 1833, misalnya putranya (Pangeran Ismail) "mati tidak wajar" di tangan adiknya (Pangeran Nokh) dalam suatu pertengkaran mengenai siapa yang akan menjadi Mangkubumi setelah Mangkubumi Nata, yang pada akhirnya meninggal tahun $1842 .^{31}$

Berbeda dengan itu, Amir Hasan Bondan (1882-1967), berpendapat bahwa Sultan Adam adalah raja yang keras, ibadat dijunjung tinggi oleh rakyat, ${ }^{32}$ sedangkan Syamsiar Seman menyatakan bahwa Sultan Adam sebenarnya lebih dikenal sebagai Sultan yang arif, karena beliau selalu berusaha untuk memajukan kesejahteraan rakyat, kemudian sebagai sultan yang dapat dikatakan santri, beliau menunjukkan perhatian guna kemajuan kesejahteraan dan agama Islam. ${ }^{33}$ Kemudian Abu Daudi mengemukakan tahwa Sultan Adam Al-Watsiq Billah adalah seorang sultan yang kuat ibadat dan berhasil menerapkan hukum Islam di kerajaan Banjar dan Banua Lima yang beliau wujudkan dalam satu undang-undang supaya rakyatnya benar-benar

${ }^{29}$ A. Ghazali Usman, Kerajaan Banjar Sejarah Perkembangan Politik Ekonomi Perdagangan dan Agama Islam, (Banjarmasin: Lambung Mangkurat University Press, 1994), h. 298.

${ }^{30}$ Pemerintah Propinsi Kalimantan Selatan, Sejarah Banjar, (Banjarmasin: Pemerintah Propinsi Kalimantan Selatan, 2003), h. 290.

${ }^{31}$ Helius Sjamsuddin, Pegustian dan Temenggung Akar Sosial Politik, Etnis dan Dinasti Perlawanan di Kalimantan Selatan dan Kalimantan Tengah 1859-1906, (Jakarta: Balai Pustaka, 2001), h. 103-104.

${ }^{32}$ Amir Hasan Kiai Bondan, Sulub Sejarah Kalimantan..., h. 35.

${ }^{33}$ Syamsiar Seman, Meninjau Naskah Lama Undang-undang Sultan Adam, Majalah Orientasi No. II, 1977, h. 4. 
menjalankan ajaran ahlusunnah wal jamaah, dan memasukkan lembaga keagamaan dalam struktur pemerintahannya yang langsung pelaksanaannya dipimpin oleh Hakim Tinggi yang terdiri dari Mufti, Qadhi dan Khalifah. ${ }^{34}$

Selanjutnya H.G. Hairul Saleh dalam kata pengantar selaku Ketua Yayasan Sulthan Adam Al-Watsiq Billah dalam buku Manaqib Sultan Adam Al Watsiq Billah mengemukakan bahwa tanpa mengurangi rasa hormat dan bangga pada raja-raja yang lainnya di kerajaan Banjar, sejarah memang telah mencatat bahwa Sultan Adam Al-Watsiq Billah adalah seorang raja yang sangat dihormati dan disegani baik oleh masyarakatnya maupun Belanda. ${ }^{35}$ Kemudian dalam Manaqib disebutkan bahwa ke 32 tahun Sultan Adam Al Watsiq Billah memerintah di Negeri Banjar, membawa rakyatnya hidup sejahtera, menegakkan ajaran ahlussunah wal jamaah, meningkatkan perekonomian serta pertanian dan mempelopori kegiatan belajar mengajar dalam bidang ilmu agama, serta mempertahankan kerajaan dari serangan penjajah baik dari pemerintah Belanda maupun dari kerajaan Inggris. Beliau pusakai kepada anak cucu dari zuriat atau keturunannya dengan semangat perjuangan dalam mempertahankan kerajaan dan undang-undang sebagai pegangan atau landasan untuk berpijak dalam menentukan segala kebijakan, memegang teguh agama, memperkokoh persaudaraan, persatuan dalam menciptakan masyarakat yang agamis untuk kemajuan bangsa dan negara. ${ }^{36}$

Mungkin masih banyak lagi pernyataan yang bersifat memuji ataupun yang bersifat mencela dari para penulis yang dapat kita kutib untuk melihat bagaimana perhatian orang tentang pribadi Sultan Adam sebagai salah satu tokoh sejarah baik lokal maupun nasional.

Sultan Adam adalah bagian dari keluarga istana Banjar yang kemudian melahirkan keturunan yang cukup banyak di lingkungan kerajaan Banjar. Sultan Adam adalah putera pertama dari Sultan Sulaiman. Beliau mempunyai saudara seibu sebapa sebanyak 5 orang dan 5 saudara sebapa 17 orang, sehingga jumlah saudara Sultan Adam sebanyak 22 orang. Dalam Manaqid Sultan Adam ${ }^{37}$ disebutkan bahwa saudara-saudara Sultan Adam adalah:

I. Yang seibu-sebapa:

1. Pangeran Husin Mangkubumi Nata.

${ }^{34}$ Abu Daudi, (2003), h. 26.

${ }^{35}$ Gusti Hairul Saleh, Manaqib Sultan Adam Al Watsiq Billah, (Martapura: Yayasan Sulthan Adam Al-Watsiq Billah, 2001), h. 4.

${ }^{36}$ Gusti Hairul Saleh, Manaqib Sultan Adam ..., h. 14.

${ }^{37}$ Gusti Hairul Saleh, Manaqib Sultan Adam ..., h. 11. 
2. Ratu Haji Musa.

3. Pangeran Perbatasari.

4. Pangeran Hashir.

5. Pangeran Sunggung Anom.

II. Yang sebapa:

1. Pangeran Berahim (Kesuma Wijaya).

2. Pangeran Ahmid.

3. Pangeran Hairun.

4. Pangeran Singasari.

5. Pangeran Dipati.

6. Pangeran Ahmad.

7. Pangeran Wahid.

8. Pangeran Thasin.

9. Pangeran Tahmid.

10. Pangeran Muhammad.

11. Pangeran Marta.

12. Pangeran Kusairi.

13. Ratu Salamah.

14. Pangeran Hasan.

15. G. Umi.

16. R. Mashud.

17. R. Karta Sari.

Yang dimaksrrd saudara seibu sebapa dengan Sultan Adam adalah anak dari Sultan Sulaiman dengan istrinya Nyai Intan Sari. Selain Nyai Intan Sari, Sultan Sulaiman masih mempunyai 8 orang istri dengan catatan istri-istri sultan, menambah istri lebih dari empat, setelah istri diantara yang empat ada yang meninggal dunia istri-istri dimaksud adalah Nyai Siti Gading, Nyai Rumangi, Nyai Unangan, Nyai Ratua, Nyai Kencana, Nyai Sari, Nyai Minah dan Nyai Taisah. ${ }^{38}$ Dari istri-istri ini lahir 17 putra-putra Sultan Sulaiman yang merupakan saudara sebapa dari Sultan Adam.

Menurut Manaqid Sultan Adam ${ }^{39}$ sekitar umur 25 tahun Sultan Adam dikawinkan dengan Nyai Ratu Kumala Sari. Dengan berdasarkan laporan Van der Ven $(1860)^{40}$ Helius Sjamsuddin menyebut Nyai Ratu Kumala Sari sebagai

${ }^{38} \mathrm{H}$. Gusti Shuria Rum, Ranji/Silsilah Raja/Sultan Kerajaan Banjar Versi Pedatuan, Makalah pada Acara Sarasehan Sejarah Kerajaan Banjarmasin, Banjarmasin, 12 Mei 2003, h. 10.

${ }^{39}$ Gusti Hairul Saleh, Manaqib Sultan Adam ..., h. 2.

${ }^{40}$ Helius Sjamsuddin, Pegustian dan Temenggung ..., h. 103. 
"tokoh yang suka mendominasi". Diceritakan pula Ratu Kumala Sari ini lebih tua 7 tahun dari Sultan Adam yang diperkirakan berasal dari Amuntai. ${ }^{41}$ Ratu Kumala Sari ini menurut banyak pengamat sejarah mempunyai pengaruh sangat besar terhadap pribadi Sultan Adam.

Dari perkawinannya dengan Nyai Ratu Kumala Sari. Sultan Adam memperoleh tujuh orang anak masing-masing:

1. Ratu Serip Husin Darma Kesuma.

2. Ratu Serip Kesuma Negara.

3. Sultan Abdurrahman.

4. Ratu Serip Abdullah Nata Kesuma.

5. Pangeran Asmail.

6. Pangeran Nuh Ratu Anom Mangkubumi Kencana.

7. Pangeran Prabu Anom.

Selain Nyai Ratu Kumala Sari, Sultan Adam masih mempunyai istri empat orang lagi dan masing-masing mempunyai keturunan. Mereka itu adalah:

1. Istri kedua bernama Nyai Endah, melahirkan Pangeran Surya Mataram.

2. Istri ketiga bernama Nyai Pe'ah, melahirkan Ratu Jantera Kusuma.

3. Istri keempat bernama Nyai Peles, melahirkan Pangeran Surya Nasaruddin.

4. Istri kelima bemama Nyai Sa'amah melahirkan Ratu Ijah.

Dengan demikian Sultan Adam mempunyai sebelas orang putra-putri sebagai pelanjut perjuangan beliau.

Selanjutnya dalam Manaqid Sultan Adam disebutkan dalam pelantikan Sultan Adam sebagai raja, maka putra tertua beliau Pangeran Abdurrahman dilantik sebagai Raja Muda dan dikenal dengan nama Sultan Abdurrahman Muda. Sultan Abdurrahman Muda itu kawin dengan Nyai Aminah (orang Tionghoa) melahirkan Pangeran Tamjid. Kemudian kawin lagi dengan Ratu Sitti, melahirkan Pangeran Hidayat. Dalam tahun 1852 Sultan Abdurrahman Muda mangkat, maka sebagai gantinya Sultan Adam menunjuk Pangeran Hidayat bin Sultan Abdurrahman Muda penggantinya sebagai Raja Muda, dan sebagai Mangkubumi beliau angkat putra beliau Prabu Anom. ${ }^{42}$

Selain Pangeran Tamjidillah dan Pangeran Hidayatullah, sultan Muda Abdurrahman masih mempunyai 10 orang anak lagi, masing-masing:

1. Pangeran Jiwa.

2. Pangeran Arya Adipati.

${ }^{41}$ Helius Sjamsuddin, Pegustian dan Temenggung ..., h. 104.

${ }^{42}$ Helius Sjamsuddin, Pegustian dan Temenggung ..., h. 13-14. 
3. Pangeran Wira.

4. Pangeran Abdullah.

5. Pangeran Ahmad.

6. Ratu Ishaq.

7. Ratu Berahim.

8. Ratu Salamah.

9. Ratu Jaya Kesuma.

10. Ratu Biduri. ${ }^{43}$

Sebagai tambahan dapat dikemukakan adanya "silsilah keluarga Raja-Raja Banjarmasin" yang dikemukakan oleh Helius Sjamsuddin yang dikutib dari sumber-sumber "Inilah Asalnya Pangeran Antasari", juga dari Verbaal 27-51904 No. L12 dan T29.Ag.2357106 yang menggambarkan bahwa Sultan Sulaiman mempunyai dua anak yaitu Khadijah dan Sultan Adam. Kemudian Khadijah kawin dengan Pangeran Mas'ud dan punya anak Pangeran Antasari dan Ratu Abdul Rahman. Ratu Abdul Rahman kawin dengan Sultan Muda Abdullah Rahman dan punya anak Pangeran Hidayatullah. ${ }^{44}$ Ranji keturunan yang demikian tidak tampak pada "Silsilah Sultan Suriansyah" yang disusun oleh H. Gusti Khairul Saleh ${ }^{45}$ sehingga banyak hal yang masih harus dikritisi dari silsilah raja-raja Banjar tersebut.

Naskah Undang-Undang Sultan Adam sebagaimana yang termuat dalam tulisan Joekes tahun 1881 yang kemudian dipublikasi ulang dalam Adatrechts Bundel 1917 hanyalah satu diantara beberapa versi Undang-Undang Sultan Adam tersebut. Naskah yang mirip juga telah dipublikasikan oleh sejarawan Banjar Amir Hasan Bondan (1882-1967) dalam bukunya Sulub Sejarah Kalimantan (1953) yang kemudian dipublikasikan lebih jauh dalam Majalah Orientasi Fakultas Hukum Universitas Lambung Mangkurat (1977) dan Akademi Hukum Sultan Adam dalam acara diskusi tanggal 22 Oktober 1986 yang merupakan lampiran dari makalah penulis "Sultan Adam dan Peranannya. Dalam perkembangan hukum di Kalimantan Selatan, yang juga diterbitkan oleh Artuum Arta dengan judul "Kitab Undang-Undang Sultan Adam 1825 (1988).

Penelitian tentang Undang-Undang Sultan Adam ini juga pernah dilakukan J. Eisenberger yang pemah menjabat sebagai Controleur van Banjarmasin en Marabahan tahun 1936 dan penulis buku "Kronick der zuider en Ooster Afdeeling van Borneo" (1936). Menurut penelitiannya naskah asli dari

\footnotetext{
${ }^{43}$ H. Gusti Shuria Rum, Ranji/Silsilah ..., h. 11.

${ }^{44}$ Helius Sjamsuddin, Pegustian dan Temenggung ..., h. 27.

${ }^{45}$ H. Gusti Khairul Saleh, Silsilab Sultan Suriansyah, (Martapura: t.tp, 2003)
} 
Undang-Undang Sultan Adam adalah dalam bentuk tulisan tangan dalam huruf Melayu Arab. Dalam penelitiannya Eisenberger menyebutkan adanya sebuah naskah tulisan tangan di Martapura tanpa tanggal tetapi diperkirakan ditulis pada tahun 1880 hanya sayangnya dokumen itu sudah tidak diketahui lagi.

Selanjutnya masih dalam penelitian Eisenberger, juga pernah ditemukan sebuah naskah yang ditulis oleh Tumanggung Soeri Koesoeno Ronggo di Banjarmasin kira-kira tahun 1885 yang naskahnya juga ditemukan dalam arsip kantor Residen Banjarmasin yang dibuat dengan tulisan tangan. Naskah ini juga ditemukan dalam arsip koleksi dari Prof. Kern, seorang ahli bahasa, sejarah dan kebudayaan lokal Indonesia.

Naskah dari Prof. Kern inilah yang dipergunakan menjadi dasar dari laporan penelitian Eisenberger dalam mempersiapkan pembentukan "Kerapatan Qodi" dan "Kerapatan Qodi Besar" di Kalimantaan Selatan sebagai lampiran dari laporannya yang berjudul "Onwerp Nopens Regeling Van de Godscchenstige Rechtspraak in de Bandjereezen gebied der zuider en Ooster afdeeling van Borneo" tanggal 26 Juli 1936 No. 1560/B 1-3, sebagaimana kemudian ditetapkan dengan Stb 1937 No. 638 dan No. 639.

Selain dari berbagai naskah yang disebutkan di atas dalam penelitian Eisenberger ditemukan pula adanya naskah yang sedikit agak berbeda dari versi-versi sebelumnya yang dapat disebut "Versi Amuntai". Naskah ini ditulis kembali oleh Asisten Residen Amuntai Helderman pada tanggal 16 April 1910. Naskah ini disalin kembali untuk keperluan kantor Inspeksi Agraria Propinsi Kalimantan Selatan tanggal 15 Februari 1972. Naskah yang sama juga tersimpan pada Biro Hukum Kantor Pemerintah Propinsi Daerah Tingkat I Kalimantan Selatan.

Dalam buku "Sejarah Banjar" yang diterbitkan oleh Pemerintah Propinsi Kalimantan Selatan, juga disajikan secara lengkap naskah Undang-Undang Sultan Adam dari Pasal 1 s/d Pasal 31, dengan catatan disebutkan pasal ini merupakan pasal terakhir dari versi Martapura, sedangkan versi Amuntai bersambung beberapa pasal lagi sampai Pasal 38. ${ }^{46}$, Naskah yang digunakan menggunakan ejaan lama dalam bahasa Melayu Banjar. Dalam buku tersebut dikemukakan bahwa Pasal 32 menurut catatan Biro Hukum adalah teks dari Pasal 33 menurut versi Amuntai. undang-undang sultan Adam menurut Versi Amuntai tersebut pasal I sampai pasal 30 isinya sama. Pasal 31 agak berbeda isinya, selanjutnya Undang-Undang Sultan Adam versi Amuntai dilanjutkan

46Pemerintah Propinsi Kalimantan Selatan, Sejarab Banjar..., h. 154-163. 
dengan Pasal 33 sampai pasal 38. Dalam uraian selanjutnya dicantumkan secara lengkap bunyi pasal $33 \mathrm{~s} / \mathrm{d} 38$ disertai dengan penjelasan. ${ }^{47}$

Berdasarkan uraian tersebut di atas, tampak kepada kita bahwa sebelum Perang Dunia II sudah tidak ditemukan lagi. Naskah asli, dari Undang-undang Sultan Adam, yang diperkirakan sudah terjadi beberapa penambahan dan perubahan dari ketentuan tersebut sebagaimana tampak pada berbagai versi yang dikemukakan di atas walaupun demikian penelitian untuk mencari naskah asli masih harus dilakukan lagi baik di Indonesia maupun di negeri Belanda.

Ketentuan hukum yang kita bicarakan ini secara formal disebut UndangUndang Sultan Adam karena dibuat oleh Sultan Adam Al Watsiq Billah seorang Sultan dari Kerajaan Banjar yang memerintah pada tahun 1825-1857. Menurut A.M. Joekes, Sultan Adam adalah seorang raja yang biasa saja dan bukan seorang ahli hukum yang kenamaan akan tetapi beliau mempunyai suatu kepekaan yang sangat tinggi sekali terhadap keadaan masyarakat di daerahnya. ${ }^{48}$

Menurut Amir Hasan Bondan, Sultan Adam adalah raja yang keras ibadah dan dijunjung tinggi oleh rakyatnya. ${ }^{49}$ Sedangkan menurut Syamsir Seman, Sultan Adam adalah sultan yang arif karena beliau selalu berusaha untuk memajukan kesejahteraan rakyat. Kemudian sebagai Sultan yang dapat dikatakan santri karena beliau menunjukkan perhatian guna kemajuan kesejahtaraan dari Agama Islam. ${ }^{50}$

Dalam "Mukadimah Undang-Undang Sultan Adam" digambarkan kapan dan untuk apa undang-undang ini dibuat. Dalam mukadimah singkat ini dikemukakan, yang kita kutib melalui berbagai versi:

- Versi Adatrecht Bundel bahasa Melayu Banjar.

" Pada hoedzrat 1251 pada hari Kamis yang ke lima belas hari boelan Almoeharam djam poekoel sembilan pada koetika itoelah akoe memboeat oendang-oendang pada sekalian ra'iatkoe dan supaja djadi sampoerna agama ra'iatkoe dan achtikat itoe dan soepaja djangan banjak djadi perbantahan mereka itoe dan soepaja djadi kamoedian segala Hakim-Hakim menghoekoemkan mereka itoe akoe harap djoea bahwa

${ }^{47}$ Pemerintah Propinsi Kalimantan Selatan, Sejarah Banjar..., h. 165-167.

${ }^{48}$ A.M. Joekes, Oendang-oendang Soelthan Adam, (Adatrehts Bundel, Dell XIII, 1917), h. 149.

${ }^{49}$ Amir Hasan Kiai Bondan, Sulub Sejarah Kalimantan, ... h. 35.

${ }^{50}$ Samsiar Seman, Meninjau Naskah Lama Undang-undang Sulthan Adam, Majalah Orientasi No. 2 Tahun. II, 1977, h. 3. 
djadi baik sekalian hal meraka itoe dengan sebab oendang-oendang ini, maka adalah oendang-oendangkoe ini beberapa perkara."

- Versi Adatrechts Bundel bahasa Belanda.

"In het jaar 1251 op Donderdag den Vijstienden dag van maand al'Moeharam's morgen te negen ure, heb ik Sultan Adam deze Verordening Uitgegenen Voor al mijne onder-danen op dat hun godsdienst en hun geloof volmakt worden en op dat tusschen hen niet Veelvuldige geschillen mogen bertaan-zoomede dat het den rechter gemaak kelijk noge worden reclrt over hen te spreken. Ik hoop zeer dat al hunne Verhoudingen door deze mijne verordening geregeld (goed) mogen worden Deze verordening bevaat de Volgende artikelen ". 52

- Versi Amuntai dalam bahasa Melayu Banjar.

"Pada hadjarat Sanah 1251 pada hari Chamis jang kelima belas hari bulan Al Moeharam djam poekoel sembilan pada ketika itulah akoe Soeltan Adam memboeat oendang-oendang pada sekalian raajatkoe dan itikat mereka itoe soepaja djangan djadi banjak pembantahan mereka itoe dan soepaja djadi kemoedahan segala chakim-chakim menghoekoemkan mereka, itoe akoe harap djoea bahwa djadi baik chal mereka itoe sebab oendang-oendangkoe ini, maka adalah oendang-2koe ini beberapa perkara. ${ }^{53}$

Dari ketentuan itu jelas bahwa undang-undang ini ditetapkan pada hari Kamis tanggal 15 Muharram $1251 \mathrm{H}$ pada jam 09.00 pagi oleh Sultan Adam. Maksud dan tujuan dikeluarkannya peraturan ini tergambar dengan jelas dari konsideran peraturan tersebut yang menyatakan bahwa Sultan Adam membuat undang-undang tersebut untuk seluruh rakyaknya dengan maksud:

1). Untuk menyempurnakan agama dan kepercayaan rakyatnya.

2). Untuk mencegak jangan sampai banyak terjadi pertentangan antara rakyat.

3). Untuk memudahkan bagi para hakim dalam menetapkan hukum.

Dan sebagai tujuan akhir dari ditetapkannya peraturan tersebut adalah agar rakyaknya dapat menjadi baik dengan adanya undang-undang tersebut. ${ }^{54}$

${ }^{51}$ Adatrechts Bundel, Vol. XIII, Borneo’s Gravenhage Martinjnus Nijhoff, 1917, h. 310.

${ }^{52}$ Adatrechts Bundel, ..., h. 343.

${ }^{53}$ Naskah, ditemukan di Kantor Inspeksi Agraria Propinsi Dati I Kalimantan Selatan, 1972, Abdurrahman, Studi Tentang Undang-undang Sultan Adam 1835, (1989), h. 123-130.

${ }^{54}$ Abdurrahman, Undang-undang Sulthan Adam dan Kedudukannya dalam Hukum Adat Banjar, Majalah Orientasi no. 2 tahun II, 1977, h. 12. 
Ditinjau dari sistematikanya undang-undang tersebut bukanlah merupakan suatu undang-undang yang baik menurut ukuran peraturan masa kini. Ia terdiri dari 31 pasal (disebut perkara, tetapi dalam bahasa Belanda diterjemahkan dengan artikel yang berarti pasal). Urutan pasal tidak disusun secara mengelompok menurut permasalahan yang diaturnya, akan tetapi kadang-kadang meloncat dan diselingkan oleh pasal yang tidak ada hubungan dengan ketentuan sebelumnya. Begitu juga aturan peralihan tidak terdapat diakhir aturan, akan tetapi ia terdapat di pertengahan.

Sistematika yang agak lain misalnya dikemukakan oleh Amir Hasan Kiai Bondan yang menyatakan bahwa Sultan Adam mengadakan Undang-undang dalam urusan peradilan yang berhubungan dengan agama, perkawinan, hak tanah dan lain-lain. ${ }^{55}$ Sedangkan Samsiar Seman membuat perincian mengenai materi yang tercakup di dalam undang-undang ini sebagai berikut:

1. Hukum Islam

2. Hukum Acara peradilan Agama Islam

3. Hukum Agararia

4. Hukum Fiskal

5. Hukum Pidana

6. Hukum Perdata

7. Dan lain-lain materi. ${ }^{56}$

Tetapi sangat disayangkan penulis tersebut tidak mencantumkan ketentuan mana yang dapat dimasukkan dalam kelompok-kelompok tersebut di atas, disamping itu pengelompokan tersebut masih sangat umum sekali sifatnya. Sedangkan rincian yang pernah penulis buat tentang kerangka sistematika Undang-Undnag Sultan Adam adalah sebagai berikut:

1. Masalah-masalah agama dan peribadatan, mencakup Pasal-Pasal 1 (Masalah Kepercayaan), 2 (Mendirikan tempat ibadat dan sembahyang berjamaah), dan Pasal 20 (Kewajiban melihat awal bulan Ramadhan/puasa).

2. Hukum Tata Pemerintahan, mencakup Pasal-Pasal 3 (Kewajiban Tetuha Kampung) dan Pasal 31 (Kewajiban Lurah dan Menteri-Menteri).

3. Hukum Perkawinan, Pasal 4 (syarat Nikah), Pasal 5 (Syarat Nikah), Pasal 6 (Perceraian), Pasal 18 (Scheiding van Tafel en bed), Pasal 25 (Menda'wa istri berzina) dan Pasal 30 (Melahirkan karena zina).

4. Hukum Acara/peradilan, Pasal 7 (Tugas Mufti), Pasal 8 (Tugas Mufti), Pasal 9 (Larangan pihak yang berperkara datang pada pejabat, Pasal (Tugas

\footnotetext{
${ }^{55}$ Amir Hasan Kiai Bondan, Sulub Sejarah Kalimantan ..., h. 33.

${ }^{56}$ Samsiar Seman, Meninjau Naskab Lama ..., h. 6.
} 
Hakim), Pasal 11 (Pelaksanaan putusan), Pasal 12 (Pengukuhan putusan), Pasal 13 (Kewajiban bilah dan kaum), Pasal 14 (surat da'waan), Pasal 15 (Tenggang waktu gugat menggugat), Pasal 19 (Larangan raja-raja atau menteri-menteri campur tangan urusan perdata kecuali ada surat dari Hakim), Pasal 24 (Kewajiban Hakim memeriksa perkara).

5. Hukum Tanah, Pasal 17 (Pendaftaran transaksi tanah), Pasal 23 (Masalah daluarsa hak atas tanah), Pasal 27 (Sewa tanah), Pasal 28 (Penggarapan tanah) dan Pasal 29 (Menterlantarkan tanah).

6. Peraturan Peralihan (Pasal 16). ${ }^{57}$

Sebagai bandingan dapat disebutkan bagaimana sistematika UndangUndang Sultan Adam dalam buku "Sejarah Banjar" yang diterbitkan oleh Pemerintah Propinsi Kalimantan Selatan. ${ }^{58}$ Dikatakan undang-undang ini mempunyai sistematika tersendiri sesuai dengan pola pikir pada saat itu, dengan sebutan perkara untuk menyebut pengertian pasal. Materi undang-undang ini dapat dikelompokkan sebagai berikut:

1. Masalah-masalah agama di peribadatan, mencakup:

Pasal 1 : Masalah kepercayaan.

Pasal 2 : Mendirikan tempat ibadat dan sembahyang berjamaah.

Pasal 20 : Kewajiban melihat awal bulair Ramadhan Puasa.

2. Masalah Hukum Tata Pemerintahan, mencakup:

Pasal 3 : Kewajiban tetuha kampung.

Pasal $21 \quad$ : Kewajiban tetuha kampung.

Pasal 31 : Kewajiban Lurah dan Mantri-Mantri.

3. Hukum Perkawinan, mencakup:

Pasal 4 : Syarat nikah.

Pasal 5 : Syarat nikah.

Pasal 6 : Perceraian.

Pasal 18 : Barambangan.

Pasal 25 : Mendakwa istri berzina.

Pasal 30 : Perzinaan.

4. Hukum Acara Peradilan, mencakup:

Pasal 7 : Tugas Mufti.

Pasal 8 : Tugas Mufti.

Pasal 9 : Larangan pihak yang berperkara datang pada pejabat.

${ }^{57}$ Abdurrahman, Sejarah Perkembangan Hukum Islam di Kalimantan Selatan, Majalah Kalimantan Scientiec, Universitas Lambung Mangkurat No. 18 Tahun VIII, 1989, h. 54-55.

${ }^{58}$ Pemerintah Propinsi Kalimantan Selatan, Sejarah Banjar... 


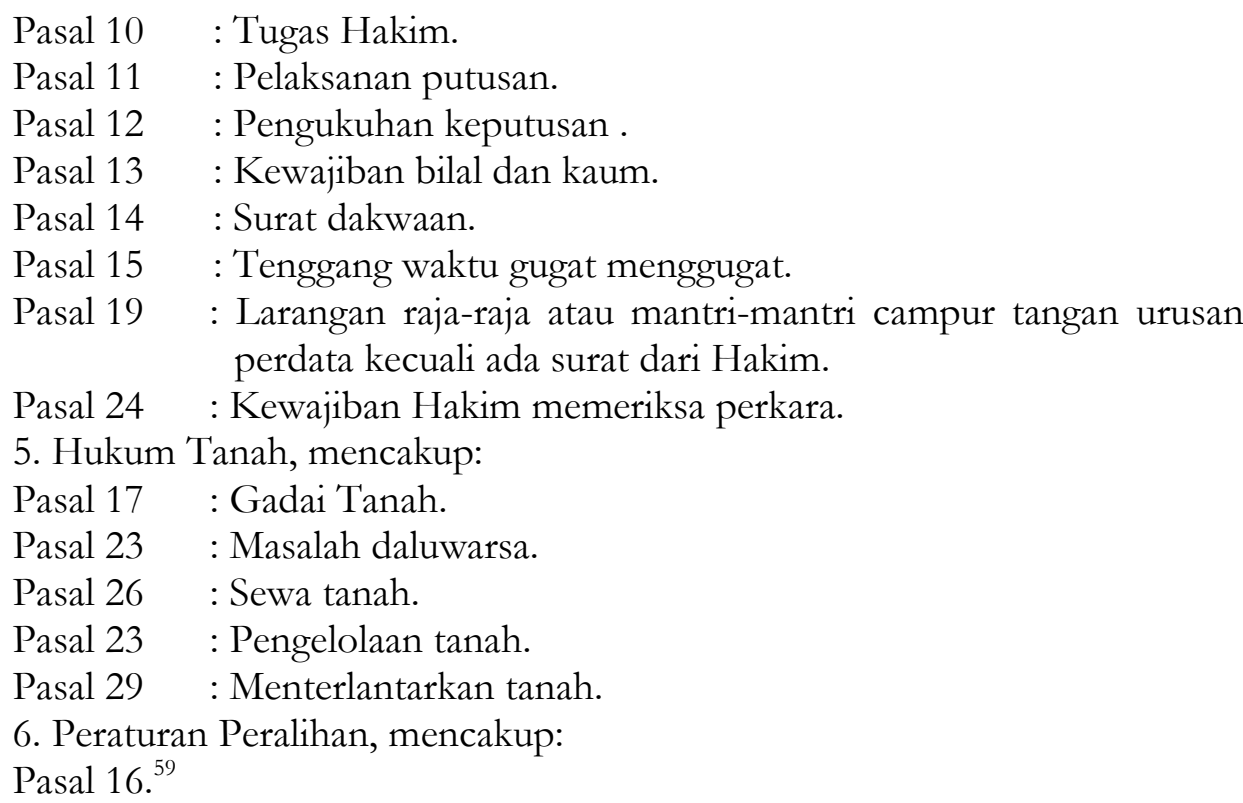

Untuk memperoleh gambaran pada bagian akhir uraian ini akan dikutib secara lengkap isi dari Pasal 31 Undang-Undang Sultan Adam Versi Martapura secara lengkap sebagai berikut:

"Mana-mana Loerah dan Mantri-Mantri Oeloe Soengai dan lainnja tiada koebariakan toeroet masoek bidara dan mengganggoe kepada segala perintah jang koetentoekan kepada sekalian Hakim-hakim dan Chalifahnya dan toean Loerahnja tiada koebariakan oempat dan ganggoe kepada sekalian perintah jang koetentoekan kepada sekaiian Hakim itoe mana-mana sekalian bitjara Hakim menghoekoem perbantahannya sekalian ra'jatkoe dan perintah jang koetentoekan kepada sekalian ra’jatkoe moefakat dan misiwarat Hakim-Hakim dan Lalawangan dan Loerah Mantrinja, kalaoe ada jang anggan dan tiada maasi hoekoem Allah tiada jang dihoekoemkan oleh hakim jaitoe sekalian Lalawangan dan Loerahnja dan Mantrinja koesoeroeh mengeraskan hoekoem itoe. Djikalaoe berkata seorang kepada saoempama Lalawangan oeloen redha bernadzar adja doea real setali dan tiba-tiba orang sampai batagih nadzar dan baqtin maka taloempat orang itoe ditagih wang panahoernja itoe tiada halal karena nadzar itoe pasid tiada sah karena ketiadaan alzam jang mewajibkan membajar dia dan djika diperoleh sjaratnja sekalipoen jaitoe tiada dikanal segala gawi dan poepoe pinta dan tiada dikanai gawi dan poepoe pinta dan tiada haroe

${ }^{59}$ Pemerintah Propinsi Kalimantan Selatan, Sejarah Banjar..., h. 151 - 152. 
biroe hak milik oeloen wadjib atas oeloen maatoeri kepada tiap-tiap moesim doea rial setali maka apabila diperoleh sjaratnja itoe wadjiblah atas mambajar dan tiada halal pembajarannja. Sekalian kepada kepala djangan ada jang menjalahi apabila ikan tiada kawa manangat lekas-lekas bapadah kajah diakoe".

Tim penyusun memberikan catatan sebagai berikut: Pada pasal ini dapat dipelajari beberapa hal tentang kerajaan Banjar ialah tentang nama-nama pejabat kerajaan, petunjuk pelaksanaan menjalankan perintah kerajaan, tentang kewajiban pembayaran nadzar dan baktin, tentang kewajiban mematuhi fatwa Mufti H. Jamaluddin.

Nama-nama pejabat kerajaan yang disebutkan dalam undang-undang ini ialah: Pembakal, Lurah, Lalawangan dan Mantri yang masing-masing menjalankan tugas sesuai dengan fungsinya. Pembakal adalah kepala dari sebuah kampung yang meliputi beberapa buah anak kampung. Lurah adalah pembantu Lalawangan yang mengamati pekerajaan beberapa pembakal dan dalam melaksanakan tugasnya Lurah dibantu oleh Khalifah, bilal dan kaum. Lalawangan adalah kepala distrik yang membawahi beberapa Lurah. Mantri adalah pangkat kehormatan untuk orang-orang yang berjasa kepada kerajaan. Beberapa diantara Mantri itu juga menjabat sebagai Lalawangan.

Petunjuk pelaksanaan untuk menjalankan tugas perintah dari kerajaan, dalam pasal ini disebutkan bahwa:

a. Pejabat-pejabat kerajaan tidak boleh mencampuri urusan peradilan.

Tugas peradilan adalah menetapkan hukum dalam beberapa perkara.

Dalam hal ini terlihat adanya semacam jaminan kebebasan peradilan seperti pada masa sekarang.

b. Pejabat-pejabat kerajaan harus mendukung dan menguatkan apa-apa yang telah menjadi keputusan Hakim. Tugas tersebut didasarkan atas permusyarawahan, (moefakat dan misiwarah). Dalam hal ini terlihat adanya semacam koordinasi pelaksanaan tugas seperti pada masa sekarang.

Dalam hal pelaksanaan tugas kerajaan ini terlihat adanya pembagiann tugas dan wewenang antara pejabat kerajaan dan tugas peradilan yang dilakukan oleh para Hakim Pejabat kerajaan tidak boleh mencampuri urusan peradilan bahkan harus menguatkan putusan pengadilan itu.

Pasal itu mengatur pula tentang kewajiban seorang warga kerajaan. Kewajiban itu ada tiga jenis berdasarkan pasal ini yaitu kewajiban membayar nadzar dan baktin dan kewajiban berbakti untuk kerajaan melalui tenaga yang disebut "gawi" dan "pupuan pinta". Kewajiban "gawi" dan "pupuan pinta" ini 
merupakan kewajiban bagi setiap warga sesuai dengan ketentuan yang sudah ditentukan. Bagi warga penduduk kerajaan yang dikenakan uang baktin yaitu dibayar dengan tenaga yaitu bekerja untuk kepentingan kerajaan tetapi dapat juga diganti dengan sejumlah uang yang besarnya sudah ditetapkan. Uang nadzar adalah kewajiban membayar dengan uang tanpa dapat diganti dengan bekerja untuk kerajaan. Kewajiban "gawi" dan "pupuan pinta" semacam pekerajaan gotong royong yang diwajibkan bagi setiap warga kerajaan.

Masalah selanjutnya dari pasal ini adalah kewajiban bagi semua warga kerajaan untuk tunduk pada fatwa Haji Jamaluddin yang menjadi Mufti Kerajaan, cucu dari Syekh Muhammad Arsyad Al Banjari. Fatwa yang bersifat dan menyangkut masalah agama terhimpun dalam Perukunan yang merupakan petunjuk praktis untuk menjalankan ibadah. Tetapi dalam pasal ini adalah kewajiban taat pada fatwa Haji Jamaiuddin Mufti Kerajaan tentang uang nadzar yang sah dan yang tidak sah. Nadzar yang sah adalah yang dinyatakan secara tegas dengan berbagai persyaratan, sedangkan nadzar yang tidak mencukupi persyaratannya adalah tidak sah kalau ada yang tidak taat pada fatwa itu penyelesaiannya diserahkan pada Sultan.

Selanjutnya kita kutib secara lengkap pasal-pasal terakhir dari UndangUndang Sultan Adam Versi Amuntai sebagaimana ditulis dalam buku sejarah Banjar disertai dengan komentar penyusun sebagai berikut:

Pasal 33:

"Sekalian orang yang handak bahoekoem kepada Kadhi di Boemi Selamat jaitoe naik dahoeloe kepada di Boetoeh atawa kepada Mangkoeboemi, maka ia berdoea itoe koesoeroeh mamariksa serta memoetoeskarr mesyawaratnya, kemoedian bawa peotoesannja kepada dieekoe dan barang jang berkehandak kepada Kadhi, maka di Boetoeh koesoeroeh memberi tjap soepaja diterima oleh Kadhi".

Pada pasal ada dua istilah yang perlu diketahui terlebih dahulu yaitu "Boemi Selamat" dan "Si Boetoeh". Bumi Selamat adalah untuk keratin Sultan di Martapura. Nama Kerajan Bumi Selamat baru dipergunakan sejak tahun 1806, sedangkan sebelumnya disebut Keraton Bumi Kencana. Tentang nama Keraton Bumi Selamat dapat dibaca pada perjanjian antara Kerajaan Banjar dengan Belanda lahir tahun 1806 tanggal 11 Agustus.

"Ini hormat sudah kita sempurnakan serta kita patrikan tiap-tiap di mana tempat paseban dalam negeri Bumi Kintjana yang sekarang ganti nama Bumi Selamat. Sebelas hari dari bulan Agustus tahun seribu delapan ratus enam". 
Sebutan "si Butuah" adalah sebutan untuk putra mahkota yaitu anak dari Sultan sendiri yang saat ini adalah Sultan Muda Abdurrahman. Sedang sebutan "ading-ading" dalam Pasal 11 maksudnya adalah Mangkubumi atau Perdana Mantri yang saat itu dijabat oleh adik Sultan sendiri yaitu Mangkubumi Kencana.

Dalam pasal ini disebutkan bahwa barang siapa yang hendak berperkara kepada Kadhi di Bumi Selamat terlebih dahulu harus datang kepada putra Mahkota Sultan Muda dan Mangkubumi dan kedua pejabat kerajaan itu harus diberi cap kerajaan dan selanjutnya dibawa kepada Sultan. Barangsiapa yang ingin meneruskannya kepada Kadhi maka putra mahkota Sultan Muda harus memberi cap kerajaan agar perkaranya diterima oleh Kadhi.

Pasal 34:

"Akan Kadhi Boemi Selamat telah moefakat sama diakoe, jang ia tiada manarima chal-chal orang melainkan jang ada tjap si Boetoeh dan tjap Mangkoeboemi, dan lagi apabila ada jang anggan daripada poetoesan Hakim jang soedah djadi tjap Mufti. Mangkoeboemi jang koesoeroeh mengarasi dengan mengikat atawa merantai".

Menurut pasal ini bahwa Kadhi telah bermufakat dengan Sultan bahwa ia tidak menerima persoalan-persoalan melainkan yang ada cap dari Sultan Muda dan Mangkubumi. Kalau orang tetap enggan atau menolak putusan itu, maka Mangkubumi diperintahkan menghukumnya dengan hukuman mengikat atau dirantai.

Pasal 35:

"apabila Kadhi Boemi Selamat mendapat kenjataan orang jang melanggar oendang-oendang atawa orang jang mendjoeal namakoe atawa nama di Boetoeh atawa nama Mangkoeboemi atawa jang mentjampoeri pekerdjaan di Boetoeh atawe pekerdjaan Mangkoeboemi Kadhi Boemi Selamat, koe-idzinkan maihoekoem orang itoe sekoerangkoerangnja setahoean".

Pasal ini menegaskan sanksi hukuman bagi orang yang melanggar undang-undang menjual nama Sultan, Sultan Muda atau menjual nama Mangkoeboemi. Kadhi Bumi Selamat diperintahkan untuk menghukum orang tersebut dengan hukuman setahun. Pasal ini merupakan satu-satunya pasal yang memuat sanksi hukuman kurungan sekurang-kurangnya setahun. Di dalam pasal ini diatur adanya beberapa tindak pidana yang diancam dengan hukum kurungan sekurang-kurangnya setahun, yaitu: 
a. Melanggar Undang-Undang Sultan Adam. Memang tidak jelas jenis melanggar undang-undang pasal berapa yang kena sanksi hukuman kurungan setahun itu. Dalam pasal-pasal sebelumnya hanya disebutkan "bapadah kajah diakoe", artinya laporkan kepada Sultan. Dalam hal ini jenis hukumannya terserah pada Sultan.

b. Menipu atau perbuatan tertentu dengan menggunakan nama Sultan untuk kepentingan keuntungan pribadi.

c. Menipu atau melakukan perbuatan tertentu dengan menggunakan nama Sultan Muda, untuk kepentingan pribadi.

d. Menipu atau perbuatan tertentu dengan menggunakan Mangkubumi, untuk kepentingan pribadi.

e. Mencampuri pekerjaan Sultan Muda Mangkubumi, maksudnya mengganggu dengan perbuatan, tindakan atau ucapan kelancaran tugas dari pejabat kerajaan tersebut.

Pasal 36:

"Barangsiapa ada kedapatan moefakat pekerdjaan kadhi dahoeloe dari pada menjampaikan kepada di Boetoeh atawa kepada Mangkoeboemi maka orang itoe koehoekoem dengan hoekoeman jang telah koeizinkan kepada Kadhi itoe jaitoe jang diseboet dalam perkara jang ketiga poeloeh lima".

Pasal ini merupakan kelanjutan dari Pasal 35, bahwa seseorang yang berperkara itu harus terlebih dahulu mengajukan kepada si Buruh dan Mangkubumi jangan langsung kepada Kadhi. Kalau diketahui menyalahi prosedur maka dikenakan hukuman seperti Pasal 35.

Pasal 37:

"Hendaklah sekalian ra'jatkoe ingat-ingat akan sekalian oendangoendangkoe ini".

Pasal ini mempertegas bahwa semua rakyat kerajaan harus memperhatikan apa yang ditetapkan dalam undang-undang ini, dengan kata lain harus mematuhinya.

Pasal 38:

"Ini oendang-oendang kepada sekalian kepala-kepala baik radja-radja atawa mantri, pambakal lainnja apabila ia koesoeroeh maka didjalankannja apa-apa jang terseboet di dalam tjapkoe itoe, maka ada jang melawan, jaitoe djikalaoe ia memboenoeh, maka tiadalah koebarikan hoekoem boenoeh kepada orang mendjalankan perintahkoe itoe". 
Pasal ini merupakan ketentuan kepada pejabat-pejabat kerajaan seperti Raja-Raja, Mantri. Pambakai atau lainnyayang menjalankan tugas kerajaan atas perintah Sultan, maka ada yang melawan dan di Penjahat itu terpaksa membunuh orang yang melawan itu, maka si Penjahat tersebut tidak dikenakan sanksi hukuman.

Undang-Undang Sultan Adam versi Amuntai ini ditutup dengan katakata yang berbunyi:

"Maka ini oendang-oendang telah moefakat akoe dengan Mangkoeboemi dan sekaitan Radja-radja dan Mantri-Mantri. Pembakal dan Toean-Toean Haji dan sekalian Kepala-Kepala adatnja".

Pasal penutup ini, menjelaskan bahwa Undang-Undang Sultan Adam ini telah mendapat persetujuan dari segala lapisan pejabat Mangkubumi, Raja-Raja, Mantri-Mantri, Pambakal dan Tuan Haji itu maksudnya adalah para alim ulama.

Demikianlah sekelumit ungkapan berkenaan dengan Undang-Undang Sultan Adam sebuah produk hukum masa lalu di kerajaan dan masyarakat Banjar yang cukup banyak mengungkapkan fakra-fakta masa lalu baik berkenaan dengan sejarah, hukum, politik dan masalah keagamaan yang punya pengaruh cukup besar dalam kehidupan masyarakat masa kini. Namun perlu disadari masih banyak sisi-sisi gelap yang belum terungkap baik mengenai substansi materi produk hukumnya sendiri, faktor-faktor yang melatar belakangi kelahirannya, maupun proses penerapan dan perubahan sosial yang ditimbulkannya.

Semua ini menuntut penelitian dan pengkajian yang lebih intensif dari para ilmuwan dan aparat pemerintah dan juga mungkin mereka yang terkait secara genelogis dengan pembentuk peraturan tersebut sehingga kita dapat mengungkap apa yang disebut sebagai sisi gelap dari sejarah masa lalu di Tanah Banjar.

Dalam kaitan tersebut pendekatan sejarah hukum sangat diperlukan mengingat Undang-Undang Sultan Adam adalah dokumen sejarah yang harus dipahami melalui kajian sejarah. Akan tetapi karena muatan dari undang-unnag adalah hukum maka kajian hukum tidak mungkin diabaikan, sehingga dengan kajian Undang-Undang Sultan Adam dalam persfektif sejarah hukum adalah merupakan pendekatan yang harus kita lakukan. 


\section{Daftar Pustaka}

Abdurrahman, Sejarah Perkembangan Hukum Islam di Kalimantan Selatan, Majalah Kalimantan Scientiec, Universitas Lambung Mangkurat No. 18 Tahun VIII, 1989.

--------, Studi Tentang Undang-undang Sultan Adam 1835, 1989.

-------, Undang-undang Sulthan Adam dan Kedudukannya dalam Hukum Adat Banjar, Majalah Orientasi no. 2 tahun II, 1977.

Abu Daudi, t.tt, t.tp, 2003.

Apeldoorn, L.J, Van, Inleding tot de Studies van het Nederlands, Leiden, Recht, 1952.

Badan Pembinaan Hukum Nasional, Simposium Sejarah Hukum, Bandung, Binacipta, 1976.

Bellefroid, J.H.P, Inleiding tot de Rechtswetenschap in Nederlands, Nijmingen Utrecht, Dakker \& van de Verg NV., 1952.

Bix, Brian H., A Dictionory of Legal Theory, Oxford: Oxford University Press, 2004.

Bondan, Amir Hasan Kiai, Sulub Sejarah Kalimantan, Banjarmasin. Fajar, 1953.

Bundel, Adatrechts, Vol. XIII, Borneo's Gravenhage Martinjnus Nijhoff, 1917, h. 310 .

Eisenberger, J., Nota Betreffende Godsdienstige Rechtspraak en de Posietie der Godsdienstige Functionarissen in The Afdeeling Banjarmasin en Hoeloe Soengai der Residentis en Oosterafdeeling Banjarmasin en Hoeloe Soengai der Residentie Zuider en Oosterafdeeling Borneo, Kern Colectie, 1936.

Encyclopaedia van Nederlandsch Indie, t.tt, t.tp, 1917.

Halidi, Yusuf, Ulama Besar Kalimantan Selatan Syekh Muhammad Arsyad Al Banjari, Surabaya, Al Ihsan, 1984.

Januri, Kyai Haji bin Haji Roys, Sejarah Kerajaan Banjar, Singapura, Al Ahmadiyah, 1975.

Joekes, A.M., Oendang-oendang Soelthan Adam, Adatrehts Bundel, Dell XIII, 1917. 
Noorlander, Johanes Cornelis, Banjarmasin en de Compagnie in de tweede helf der 18de Eeuw, Leiden, M. Dubbeldeman, 1935.

Pemerintah Provinsi Kalimantan Selatan, Sejarah Banjar, Banjarmasin, Pemerintah Provinsi Kalimantan Selatan, 2003.

Poedjosewajo, Kusnadi, Pedoman Pelajaran Tata Hukum Indonesia, t.tp, Universitas, 1962.

Pound, Roscoe, Interpretation of Legal History, Florida, Wm W Gaunt \& Soon Inc, 1985.

Rum, H. Gusti Shuria, Ranji/Silsilab Raja/Sultan Kerajaan Banjar Versi Pedatuan, Makalah pada Acara Sarasehan Sejarah Kerajaan Banjarmasin, Banjarmasin, 12 Mei 2003.

Saleh, Gusti Hairul, Manaqib Sultan Adam Al Watsiq Billah, Martapura, Yayasan Sulthan Adam Al-Watsiq Billah, 2001.

-------, Silsilab Sultan Suriansyah, Martapura, t.tp, 2003.

Saleh, M. Idwar, Banjarmasin, Selayang Pandang Mengenai Bangkitnya Kerajaan Banjarmasin, Posisi, Fungsi, dan Artinya dalam Sejarah Indonesia dalam Abad ke 17, Bandung, Balai Pendidikan Guru, 1957.

Seman, Samsiar, Meninjau Naskah Lama Undang-undang Sulthan Adam, Majalah Orientasi No. 2 Tahun. II, 1977.

Shiddiq, Syekh Abdurrahman, Risalah Sejaratul Arsyadiyah, Singapura, Jakarta, Maktabaah Ahmadiyah, 1937.

Sjamsuddin, Helius, Pegustian dan Temenggung Akar Sosial Politik, Etnis dan Dinasti Perlawanan di Kalimantan Selatan dan Kalimantan Tengab 1859-1906, Jakarta, Balai Pustaka, 2001.

Soekanto, Soerjano, Pengantar Sejarah Hukum, Bandung, Alumni, 1979.

Team Penyusun, Manaqid Sultan Adam Al-Watsiq Billah Martapura Kalimantan Selatan, Kalimantan Selatan, Yayasan Sultan Adam Al-Watsiq Billah, 2001.

Usman, A. Ghazali, Kerajaan Banjar Sejarab Perkembangan Politik Ekonomi Perdagangan dan Agama Islam, Banjarmasin, Lambung Mangkurat University Press, 1994. 
Utrecht, E., Pengantar dalam Hukum Indonesia, Jakarta, Ichtiar, 1966.

Vollenhoven, Van, Het Adatrecht V an Nederlandsch Indie, t.tt, t.tp, 1905. 